\title{
Long- and short-term changes in social wasp community structure in an urban area
}

\author{
M Detoni, BC Barbosa, TT Maciel, SJl dos Santos, F Prezoto
}

Laboratório de Ecologia Comportamental e Bioacústica - LABEC, Departamento de Zoologia, Universidade Federal de Juiz de Fora, MG, Brazil

\section{Article History}

\section{Edited by}

Marcel Hermes, UFLA, Brazil

Received

27 October 2017

Initial acceptance

Final acceptance

Publication date

30 January 2018

30 January 2018

09 July 2018

\section{Keywords}

Nesting, Polistinae, synanthropism.

\section{Corresponding author}

Mateus Fajardo de Freitas Salviato Detoni Laboratório de Ecologia Comportamental e Bioacústica - LABEC

Universidade Federal de Juiz de Fora

Campus Universitário

Bairro Martelos - CEP 36036-900

Juiz de Fora, Minas Gerais, Brasil.

E-Mail: matedetoni@hotmail.com

\begin{abstract}
The success of social wasps in anthropic environments is related to their ability to nest both in vegetation and human constructions, and, as humans modify their own environments, wasps community structure may shift as well. Our aim was to assess the diversity of social wasps and their interactions with nesting substrates seasonally in an urban squares area in Southeastern Brazil, 15 years after the first diversity study in this area. We actively searched for nests in the rainy season between 2014 and 2015 and in the dry season of 2015. Although social wasp species richness did not change since the 2000 assessment (13 species in 5 genera), the abundance decreased substantially. Additionally, wasps showed a general trend of nesting on the man-made materials Metal ( $n=115,60 \%$ ) and Concrete ( $n=106,36 \%$ ), especially by the two most common species sampled: Mischocyttarus cassununga and Polistes versicolor. We suggest that abundance decrease may correspond to the reduction of green areas in the assayed locations. These results support the well-known importance of maintaining green areas in urban environments to promote the growth and conservation of diverse social wasp communities.
\end{abstract}

\section{Introduction}

The social wasps are widely distributed throughout all continents, except Antarctica. In Brazil, they are represented primarily by the Polistinae (Carpenter \& Marques, 2001). Brazilian paper wasps inhabit various environments, but show high degrees of association with urban areas, often constructing nests under or inside the walls of buildings (Wenzel, 1998; Alvarenga et al., 2010; Torres et al., 2014; Michelutti et al., 2013).

The importance of studying social wasps and their diversity is emphasized by their ecological roles. For instance, social wasps may act as pollinators when visiting flowers (Clemente et al., 2012), detritivores when foraging on decaying fruits (Barbosa et al., 2014) and animal carcasses (Moretti et al., 2011), and predators when foraging on agricultural pests (e.g., caterpillars) (Elisei et al., 2010). As a result, social wasps are part of a complex intra and interspecific ecological web that is yet to be fully comprehended (Menezes et al., 2014; Virgínio et al., 2016).
The nesting sites chosen by wasps are strongly influenced by predation and the weather (Raposo-Filho \& Rodrigues, 1984; Souza et al., 2010). Nesting on manmade substrates, in addition to natural ones, may be a useful strategy for wasp populations since their colonies may have higher developmental success as these locations may allow them to avoid their natural predators and take shelter from harsh weather conditions (Jeanne, 1975; Lima et al., 2000; Alvarenga et al., 2010).

Studies with social wasp behavior and diversity in urban environments have been increasing in number in the last decade (e.g. Alvarenga et al., 2010; Jacques et al., 2012; Naldoski, 2013; Torres et al., 2014; see Barbosa et al., 2016). They show the relation between many species of social wasps and their environments, such as how some species found in urban areas depend exclusively on natural vegetation, whereas other prefer artificial substrates (Alvarenga et al., 2010; Sinzato et al., 2011; Castro et al., 2014; Virgínio et al., 2016). Moreover, as humans continue to change their 
environment, some species seem to change their nesting preferences as well (Torres et al., 2014). Other studies discuss these nesting tendencies in natural and urban areas (Lima et al., 2000; Alvarenga et al., 2010; Maciel and Barbosa, 2015), explaining the advantages of using both natural and man-made substrates. Thus, we need to better understand the ecological relations between wasps and the urban environment.

Previous studies have begun comparing nesting preferences in natural vs. artificial environments. Here, we build on that previous work to survey the diversity of social wasps, using urban locations surveyed in a study published 15 years prior to this one (Lima et al., 2000). We compare the two sets of results to understand long-term changes in the social wasp community structure. We also investigated short-term seasonal changes in the social wasp community structure, by investigating population dynamics across two following seasons and studied the interactions between the species of social wasps and their nesting substrates, trying to establish a link between this relation and the group's seasonality and diversity in order to better understand the ecology of social wasps in urban areas.

\section{Material and Methods}

Area of study

The study was carried out in the campus of Universidade Federal de Juiz de Fora (UFJF) (21 ${ }^{\circ} 46^{\prime} 02.72^{\prime}$ 'S $-43^{\circ} 22^{\prime} 34.9^{\prime \prime} \mathrm{W} 678 \mathrm{~m}$ asl), located within the urban perimeter of Juiz de Fora, Minas Gerais state, Southeastern Brazil. The climate in the area is characterized as humid subtropical, with dry winters (May to September) and rainy summers (October to April) (Cwa), according to Köppen-Geiger (Sá-Júnior et al., 2012). The area has been recently classified by Carvalho et al. (2014) as having a predominance of Pinus elliottii Engelm., showing a low diversity of plant species, and is considered an emergent ecosystem (Fig 1). It may also be referred to as a novel ecosystem (Maciel \& Barbosa, 2015).

\section{Data sampling}

Recording the wasp nests took place during one dry season (between December 2014 and February 2015), and one rainy season (between June and July 2015). We actively searched for colonies by inspecting man-made substrates (further classified into: asbestos, concrete, ceramic, metal, plastic, porcelain or stone), rocky outcrops, tree trunk cavities and canopies. When they were located, we photographed colonies, identified the material used as substrate, and collected 1-3 individuals with an entomological net. Individuals were stored in labeled containers with $70 \%$ ethylic alcohol for later identification.

For species identification, we used dichotomous keys suggested by Richard (1978), Hermes and Kohler (2004), Silveira (2008), Andena et al. (2009) and Carpenter and Andena (2013). Wasp samples were stored in the Laboratório de Ecologia Comportamental e Bioacústica (LABEC) of UFJF; one individual of each species was dry mounted for the voucher.
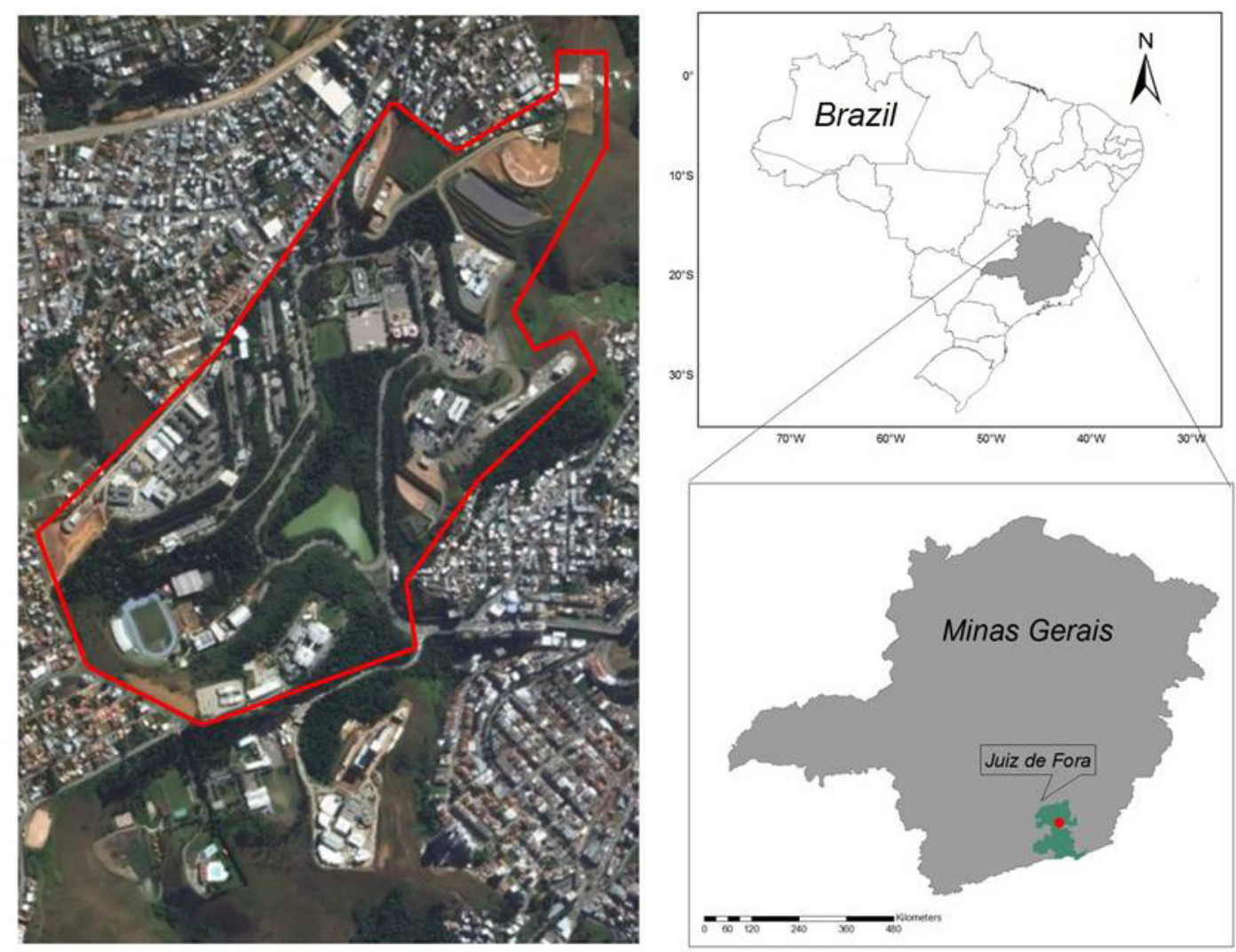

Fig 1. Geographical representation of area of the campus of Universidade Federal de Juiz de Fora, delimited in red, in the urban perimeter of Juiz de Fora, Minas Gerais state, southeastern Brazil. 
Data analysis

Species diversity was analyzed for Rainy and Dry season separately and combined using the Shannon $\left(\mathrm{H}^{\prime}\right)$ diversity index and the H'-based Pielou (J') evenness index. The PAST v.2.17c software (Hammer et al., 2001) was used to perform diversity analyses. G-Test was used to examine the difference in wealth and abundance between seasons; calculations were done with the BioEstat software (v. 5.3).

Each species' dominance was calculated and expressed as a percentage using the following formula: $\mathrm{D}=(\mathrm{i} / \mathrm{T})^{*} 100$, where $\mathrm{i}=$ total number of individuals of a given species and $\mathrm{T}=$ total number of individuals of all species collected. These percentages were then categorized as follows: eudominant $>$ $10 \%$; dominant $=5-10 \%$; subdominant $=2-5 \%$; recessive $=$ 1- $2 \%$; or rare $<1 \%$ (Friebe, 1983).

In order to assess social wasp species richness in the area for each used method, we calculated the species' rarefaction curves (sensu Gotelli \& Colwell, 2001) through the software EstimateS 9 using 5000 randomizations. First and $2^{\text {nd }}$ order non-parametric estimators of Jackknife were used to project the maximum species richness that each method and area of study may reach. The software generates 5000 species accumulation curves, randomizing the sampling order; therefore, each point on the curve corresponds to the average of the accumulated richness for the 5000 curves and is associated to a standard deviation value.

To design the bipartite graph among substrates and social wasps on the campus of UFJF, we used every colony in order to build an adjacency matrix for each season: a "quantitative matrix" that regards the frequency of nestsubstrate interactions for each wasp species through the $\mathrm{R}$ software (v.3.4.3).

In order to assess general changes in the composition of the environment, we obtained satellite photographs of the campus area from the software Google Earth Pro 7.3.0.3832 (32-bit) for the years of 2015 and 2010, which was the oldest record available. Green areas were calculated in the same software using an area delimiting tool. Additional data for previous years was obtained from Vieira et al. (2016).

\section{Results}

We identified a total of 13 species from five genera: Mischocyttarus Saussurre, 1853, Polistes Latreille, 1902, Polybia Lepeletier, 1836, Protopolybia Ducke, 1905 and Synoeca de Saussure, 1852 (Table 1). Species richness was significantly higher during the rainy season ( $\mathrm{n}=13$ species) compared to the dry season ( $n=8$ species; G-Test $=36.0685 ; p<0.0002$; Table 1 ).

The abundance of colonies was also higher during the rainy season ( $\mathrm{n}=197$ colonies) compared to the dry season ( $\mathrm{n}$ $=86$ colonies $)(283$ total, average $=141.5 ;$ G-Test $=366.8213$; $\mathrm{p}<0.0001)$.

There were two eudominant species in the area, Mischocyttarus cassununga (von Ihering, 1903) and Polistes versicolor (Olivier, 1791), and one dominant, Protopolybia exigua (de Saussure, 1854). The remaining species were fit into subdominant, recessive or rare (Table 1). Tests with the Jacknife estimators of $1^{\text {st }}$ and $2^{\text {nd }}$ order showed an estimation of 16 and 17 species (respectively) to the campus of UFJF.

Table 1. Species of social wasps sampled and values calculated for Shannon's index, Dominance index and Pielou's index at the campus of Universidade Federal de Juiz de Fora, city of Juiz de Fora, Minas Gerais state, Southeastern Brazil, in the periods between December 2014 and January 2015 (rainy season) and between June and July 2015 (dry season).

\begin{tabular}{lccccc}
\hline \multicolumn{1}{c}{ Species } & Rainy Season & $\begin{array}{c}\text { Frequency } \\
\text { Dry Season }\end{array}$ & Total & \multicolumn{2}{c}{ Dominance } \\
\hline Mischocyttarus socialis (de Saussure, 1854) & 1 & 0 & 1 & Rare & 0,4 \\
Mischocyttarus cassununga (von Ihering, 1903) & 100 & 49 & 149 & Eudominant & 52,7 \\
Mischocyttarus drewseni Saussure, 1954 & 10 & 3 & 13 & Subdominant & 4,6 \\
Mischocyttarus wagnei (Buysson, 1908) & 1 & 0 & 1 & Rare & 0,4 \\
Polistes ferreri (de Saussure, 1853) & 7 & 2 & 9 & Subdominant & 3,2 \\
Polistes versicolor (Olivier, 1791) & 46 & 16 & 62 & Eudominant & 21,9 \\
Polybia fastidiosuscula Saussure, 1854 & 1 & 1 & 2 & Rare & 0,7 \\
Polybia paulista (Ihering, 1896) & 1 & 1 & 2 & Rare & 0,7 \\
Polybia platycephala Richards, 1951 & 7 & 0 & 7 & Subdominant & 2,5 \\
Polybia sp. & 3 & 2 & 5 & Recessive & 1,8 \\
Protopolybia exigua (de Saussure, 1854) & 16 & 12 & 28 & Dominant & 9,9 \\
Protopolybia sedula (de Saussure, 1854) & 3 & 0 & 3 & Recessive & 1,1 \\
Synoeca cyanea (Fabricius, 1775) & 1 & 0 & 1 & Rare & 0,4 \\
Total & 197 & 86 & 283 & - & - \\
Rainy season & $\mathrm{H}^{\prime}=0,6678$ & $\mathrm{~d}=0,5076$ & $\mathrm{~J}=0,5995$ & & \\
Dry season & $\mathrm{H}^{\prime}=0,5682$ & $\mathrm{~d}=0,5823$ & $\mathrm{~J}=0,6292$ & & \\
Total & $\mathrm{H}^{\prime}=0,6477$ & $\mathrm{~d}=0,5265$ & $\mathrm{~J}=0,5814$ & & \\
\hline
\end{tabular}


These results, along with the species rarefaction curve, are depicted in Figure 2.

Regarding the nesting substrates, social wasps constructed nests on metal the most (115 nests, $40 \%$ of the total sampled colonies), followed by concrete (102 nests, $36 \%)$. The remainder of the nests (24\%) was divided somewhat evenly among the remaining substrates. The eudominant species (M. cassununga and P. versicolor) have shown flexibility regarding the nesting substrates, found on six and five (respectively) of the eight substrates used by wasps on this study (Figure 3). P. exigua, Protopolybia sedula (de Saussure, 1854) and Synoeca cyanea (Fabricius, 1775), on the other hand, exclusively used vegetation as their substrate. It is worth noting that the use of vegetation as nesting substrate was $43 \%$ lower in the dry season than in the rainy season. Such reduction was also recorded for the species richness on this substrate, which decreased from six to only two species in the dry season.

The investigation of the green areas within the campus between 2010 and 2015 showed that in 2010 the total green area was $496,966.9 \mathrm{~m}^{2}$, which corresponds to $36.9 \%$ of the total campus area $\left(1,346,793.80 \mathrm{~m}^{2}\right)$. The green area in 2015 was reduced to $334,004.8 \mathrm{~m}^{2}$, corresponding to $24.8 \%$ of the total campus area; a reduction of $12.1 \%$ of green area. Additionally, Vieira et al. (2016) described a 7.36\% reduction of green areas in the campus between 2002 and 2010. By combining these data, we calculate that, between 2002 and 2015 , green areas in the campus decreased in $18.56 \%$.

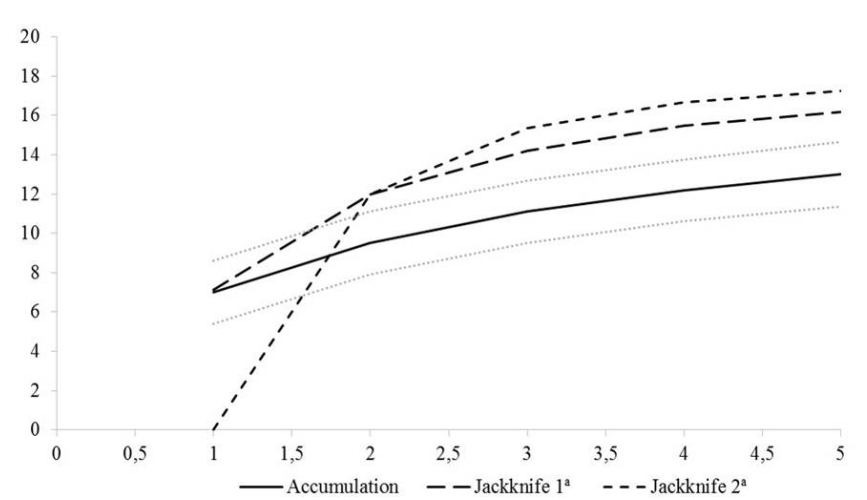

Fig 2. Species Rarefaction Curves estimated from 5000 randomizations for the social wasps sampled in the campus of Universidade Federal de Juiz de Fora city of Juiz de Fora, Minas Gerais state, Southeastern Brazil, in the periods between December 2014 and January 2015 (rainy season) and between June and July 2015 (dry season).

\section{Discussion}

Comparing the diversity of wasps sampled in this study with the results found by Lima et al. (2000) in the same area 15 years before provides various insights on how changes in the environmental structure of urban areas may affect the social wasp fauna. In terms of genera richness, both studies had very similar structures since they shared four genera (Mischocyttarus, Protopolybia, Polistes and Polybia) and presented a single exclusive genus each (Protonectarina in Lima et al., 2000, Synoeca in this study). These exclusive genera comprise very small portions of the samples (two colonies of Protonectarina and one of Synoeca) and show similarities in nesting habits (notably a preference for nesting almost exclusively in vegetation, according to Richards \& Richards, 1951; Wenzel, 1998). Their presence may therefore represent rare occurrences rather than an actual change in the richness structure between those 15 years.

The abundance of social wasps, on the other hand, has shown greater differences between the two studies in the area. While Lima et al. (2000) sampled a mean 287.75 colonies per census, we found less than half this value (141.5 per census). This alarming decrease in the wasp populations may be a result of the progressive reduction of vegetation in the studied site. Many tropical wasp species nest exclusively on vegetal substrate, and all benefit indirectly from the surrounding green areas, especially in urban areas (Wenzel, 1998; Alvarenga et al., 2010). Although it cannot be concluded, we suggest that the significant decrease of vegetation (close to $20 \%$ in 15 years) may have played a major role in determining social wasp abundance in the area.

Our data seems to be in accordance with the richness of social wasps shown in environments with some degree of similarity to the campus. Jacques et al. (2012) studied an urban area with integrated vegetation in Southeastern Brazil and sampled 21 species; however, only 7 genera and 13 of these species were recorded through the active nest search method, which is similar to our results (13 spp. in five genera). Other diversity studies performed in natural areas show some variation regarding richness; for instance, in the Atlantic Rainforest, these values range between 10 (Arab et al., 2010), 18 (Santos et al., 2007) and 25 (Hermes \& Köhler, 2004), highlighting the importance of urban areas, since the value we sampled $(\mathrm{n}=13)$ is within their range.

Similar to Lima et al. (2000) we found that the abundance and species richness of social wasps is higher during the rainy season compared to the dry season. This is an evidence of a high colony cycle synchrony degree, as described for some independent-founding wasps (Dantas de Araujo, 1982). However, since $61.5 \%$ of the species were also present in the winter, our results agree with Naldoski (2013), who suggests that the complexity of urban environments reduces the impact of seasons on the social wasp cycles.

Despite the differences in abundance and diversity between seasons, the ecological indices had low variation when values were compared across seasons and throughout the year. Jacques et al. (2012) calculated diversity and dominance of social wasps in a different urban area in Southeastern Brazil, and their sample showed higher diversity $\left(H^{\prime}=0.9814\right)$ and lesser dominance $(D=0.2581)$ than ours. This results suggests the fauna in the campus of Universidade Federal de Juiz de Fora is strongly dominated by a few species. Indeed, 
our samples showed two eudominant species (M. cassununga and $P$. versicolor) and a dominant one (Protopolybia exigua), the rest being subdominant, recessive or rare. The fact that the structure of the index does not significantly differ between seasons suggests that highly dominant species are more adapted to persist throughout harsher (i.e., dryer) environmental conditions.

The species $M$. cassununga and $P$. versicolor may be considered highly synanthropic, since they are more consistently abundant compared to other species (Torres et al., 2014; Castro et al., 2014). In our study, the swarming species (Epiponini tribe) used larger substrate area to attach their large nests. Moreover, the species of the Epiponini tribe were recorded less often on man-made substrates, and some species were restricted to constructing nests on vegetation (Jeanne, 1975; Carpenter \& Marques, 2001). In other words, in an environment where green areas are receding (Vieira et al., 2016), species capable of nesting preferably on artificial structures - here depicted by the eudominant $M$. cassununga and $P$. versicolor nesting on metal and concrete (see Figure 3) - are more successful in occupying an urban environment.

Our results show that although the species richness of social wasps in the campus of UFJF has been relatively stable over the last 15 years, modifications on the campus' physical structure, with more buildings and less vegetation, may be affecting the relative abundance of wasps and allowing certain species that are capable of nesting on man-made structures to dominate the community. This is clearly seen in the overall reduction of social wasp abundance over the past 15 years, as well as the decrease of species richness from rainy to dry seasons. Altogether, these results highlight the importance of maintaining green areas in order to promote the growth and conservation of wasp populations.

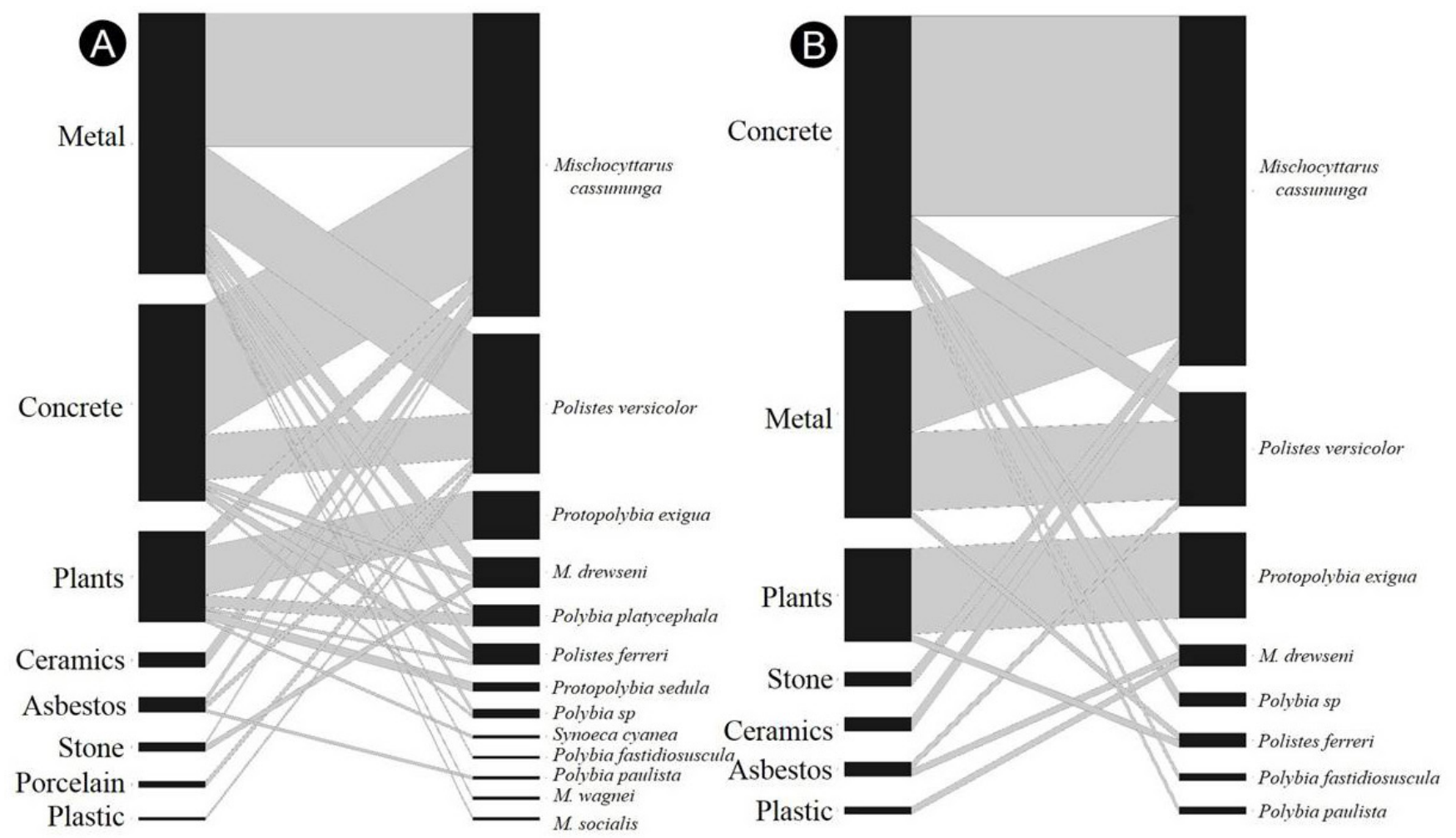

Fig 3. The relation between wasps and different nesting substrates, involving 13 species of social wasps and eight types of substrate on the campus of Universidade Federal de Juiz de Fora, Juiz de Fora, Minas Gerais state, Southeastern Brazil. A - Rainy season (hot/humid) and B - Dry season (cold/dry).

\section{Acknowledgements}

The authors would like to thank Dr. Jennifer Jandt of the University of Otago for her suggestions in the writing of this paper. We would also like to thank the Universidade Federal de Juiz de Fora (UFJF) and Conselho Nacional de Pesquisa e Desenvolvimento (CNPq) (F. Prezoto 310713/ 2013-7) for financial support.

\section{References}

Alvarenga RB, Castro MM, Santos-Prezoto HH, Prezoto F (2010). Nesting of social wasps (Hymenoptera, Vespidae) in urban gardens in Southeastern Brazil. Sociobiology 55: 445-452.

Arab A, Cabrini I, de Andrade CFS (2010). Diversity of polistinae wasps (Hymenoptera, Vespidae) in fragments of Atlantic Rain Forest with different levels of regeneration in Southeastern Brazil. Sociobiology, 56 (2): 515-526. 
Barbosa BC, Detoni M, Maciel TT, Prezoto F (2016). Studies of social wasp diversity in Brazil: Over 30 years of research, advancements and priorities. Sociobiology, 63 (3): 858-880. doi: 1 0.13102/sociobiology.v63i3.1031

Barbosa BC, Paschoalini M, Prezoto F (2014). Temporal Activity Patterns and Foraging Behavior by Social Wasps (Hymenoptera, Polistinae) on Fruits of Mangifera indica L. (Anacardiaceae). Sociobiology, 61 (2): 239-242. doi: 10.13102/sociobiology.v61i2.239-242

Carpenter JM, Andena SR (2013). The vespidae of Brazil, Manaus, Instituto Nacional de Pesquisa da Amazônia, Manaus, Brazil.

Carpenter JM, Marques OM (2001). Contribuição ao estudo dos vespídeos do Brasil (Insecta, Hymenoptera, Vespoidea, Vespidae). Publicações Digitais, 2: 1-147.

Carvalho FA, Abreu RC, Barros KART, Fonseca SN, Santiago DS, Oliveira DE, Furtado, S.G. (2014). A comunidade arbórea regenerante de um 'ecossistema emergente' dominado pela espécie exótica invasora Pinus elliottii Engelm. Interciencia, 39: $307-312$.

Castro MM, Avelar DLG, De Souza AR, Prezoto F (2014) .Nesting substrates, colony success and productivity of the wasp Mischocyttarus cassununga. Revista Brasileira de Entomologia, 58: 168-172.

Clemente MA, Lange D, Del-Claro K, Prezoto F, Campos, NR, Barbosa BC (2012) Flower-visiting social wasps and plants interaction: Network pattern and environmental complexity. Psyche: A Journal of Entomology, 2012: 1-10. doi: $10.1155 / 2012 / 478431$

Dantas de Araujo CA (1982). Bionomia comparada de Myschocyttarus [sic.] drewseni drewseni das espécies subtropical (Curitiba, PR) e tropical (Belém, PA) do Brasil (Hymenoptera, Vespidae). Dusenia, 13: 165-172.

Elisei T, Nunes JVE, Ribeiro Junior C, Fernandes Junior AJ, Prezoto F (2010). Uso da vespa social Polistes versicolor no controle de desfolhadores de eucalipto. Pesquisa Agropecuária Brasileira, 45: 958-964. doi: 10.1590/S0100204X2010000900004

Friebe B (1983). Zur Biologie eines Buchenwaldbodens: 3 . Die Kaferfauna, 41:45-80.

Gotelli NJ, Colwell RK (2001) Quantifying biodiversity: procedures and pitfalls in the measurement and comparison of species richness. Ecology Letters, 4: 379-391. doi: 10. 1046/j.1461-0248.2001.00230.x

Hammer Ø, Harper DAT, Ryan PD (2001). PAST: Paleontological Statistical software package for education and data analysis. Palaentologia Electronica, 4: 1-9.

Hermes MG, Köhler A (2004). Chave ilustrada para as espécies de Vespidae (Insecta, Hymenoptera) ocorrentes no
Cinturão Verde de Santa Cruz do Sul, RS, Brasil. Caderno de Pesquisa Série Biologia (UNISC), 16: 65-115.

Jacques, GC, Castro AA, Souza GK, Silva-Filho R, Souza MM, Zanuncio JC (2012). Diversity of Social Wasps in the Campus of the Universidade Federal de Viçosa in Viçosa, Minas Gerais State, Brazil. Sociobiology, 59 (3): 1053-1062.

Jeanne RL (1975). The adaptiveness of social wasps nest architecture. The Quarterly Review of Biology, 50: 267-287.

Jeanne RL (1991). The swarm-founding Polistinae. In KG Ross \& RW Matthews (Eds.), The Social Biology of Wasps (pp. 389-425). Ithaca: Cornell University Press.

Lima MAP, Lima JR, Prezoto F (2000). Levantamento dos gêneros de vespas sociais (Hymenoptera, Vespidae), flutuação das colônias e hábitos de nidificação no campus da UFJF, Juiz de Fora, MG. Revista Brasileira de Zoociências, 2: 69-80.

Maciel TT, Barbosa BC (2015). Áreas Verdes Urbanas: História, Conceitos e Importância Ecológica. CES Revista, 29: 30-42.

Menezes JCT, Barbosa BC, Prezoto F (2014). Previously unreported nesting associations of Yellow-Olive Flycatcher (Tolmomyias sulphurescens) (Aves: Tyrannidae) with social wasps and bees. Ornitología Neotropical, 25: 363-368.

Michelutti KB, Montagna TS, Antonialli-Junior WF (2013). Effect of anthropic influence on the colonial productivity of the social wasp Mischocyttarus consimilis (Hymenoptera, Vespidae). Sociobiology, 60 (1): 96-100. doi: 10.13102/ sociobiology.v61i1.100-106

Moretti TDC, Giannotti E, Thyssen PJ, Solis DR, Godoy WAC (2011). Bait and habitat preferences, and temporal variability of social wasps (Hymenoptera: Vespidae) attracted to vertebrate carrion. Journal of Medical Entomology, 48 (5): 1069-1075. doi: 10.1603/ME11068

Naldoski J (2013). Phenology of European Hornet, Vespa cabro L. and Saxon Wasps, Dolichovespula saxonica Fabr. (Hymenoptera: Vespidae): the Influence of the Weather on the Reproductive Success of Wasp Societies in Urban Conditions. Sociobiology, 60 (4): 477-483. doi: 10.13102/sociobiology. v60i4.477-483

Raposo-Filho JR, Rodrigues VM (1984). Habitat e local de nidificação de Mischocyttarus (Monocyttarus) extinctus Zikán, 1935. (Polistinae - Vespidae). Anais da Sociedade Entomológica do Brasil, 13: 19-28.

Richards OW (1978). The social wasps of the Americas excluding the Vespinae. London, UK: British Museum (Natural History).

Richards OW, Richards MJ (1951). Observations on the social wasps of South America (Hymenoptera Vespidae). Ecological Entomology, 102 (1): 1-169.

Sá Júnior A, Carvalho LG, Silva FF, Carvalho Alves M (2012). Application of the Köppen classification for climatic 
zoning in the state of Minas Gerais, Brazil. Theoretical and Applied Climatology, 108: 1-7.

Santos GMM, Filho CCB, Resende JJ, Cruz JD, Marques OM (2007). Diversity and community structure of social wasps (Hymenoptera: Vespidae) in three ecosystems in Itaparica Island, Bahia State, Brazil. Neotropical Entomology, 36: 180-185.

Silveira OT (2008). Phylogeny of wasps of the genus Mischocyttarus de Saussure (Hymenoptera, Vespidae, Polistinae). Revista Brasileira de Entomologia, 54: 510-549.

Sinzato DM, Andrade FR, De Souza AR, Del-Claro K., Prezoto F (2011). Colony cycle, foundation strategy and nesting biology of a Neotropical paper wasp. Revista Chilena de Historia Natural, 84: 357-363.

Torres RF, Torres VO, Súarez YR, Antonalli-Junior WF (2014). Effect of the Habitat Alteration by Human Activity on
Colony Productivity of the Social Wasp Polistes versicolor (Olivier) (Hymenoptera: Vespidae). Sociobiology, 61: 100-106.

Vieira KM, Netto P, Amaral D, Mendes SS, Catro LC, Prezoto $F$ (2016). Nesting stingless bees in urban areas: a reevaluation after eight years. Sociobiology, 63(3): 858-880.

Virgínio F, Maciel TT, Barbosa BC (2015). Nidificação de Polybia rejecta (Fabricius) (Hymenoptera: Vespidae) Associada à Azteca chartifex Forel (Hymenoptera: Formicidae) em Ecótono de Bioma Caatinga/Mata Atlântica, no Estado do Rio Grande do Norte. EntomoBrasilis, 8(3): 242-245.

Virgínio F, Maciel TT, Barbosa BC (2016). Hábitos de Nidificação de Polistes canadensis (Linnaeus) (Hymenoptera: Vespidae) em Área Urbana. EntomoBrasilis, 9(2): 81-83.

Wenzel JW (1998). A generic key to the nests of hornets, yellow jackets, and paper wasps worldwide (Vespidae: Vespinae, Polistinae). American Museum Novitates, 3224: 1-39. 